\title{
Uptake of Cadmium by Pseudokirchneriella supcapitata
}

\author{
Magela Paula Casiraghi ${ }^{1}$, Samuel Luporini ${ }^{1 *}$ and Eduardo Mendes da Silva ${ }^{2}$ \\ ${ }^{1}$ Departamento de Engenharia Química; Escola Politécnica; Universidade Federal da Bahia; 40210-630; Salvador- \\ BA - Brasil. ${ }^{2}$ Departamento de Biologia; Universidade Federal da Bahia; 40170-290; Salvador - BA - Brasil
}

\begin{abstract}
In this work the microalgae Pseudokirchneriella supcapitata was used for the removal of the cadmium in liquids. The accumulations of metal ions by the alga occur in two stages: a very fast absorption (passive adsorption) proceeded by a slower absorption (activate absorption). A mathematical model based on the surface absorption and on the transport into the interior of the cellular membrane was developed. The simulation model kinetic parameters were experimentally obtained. Through the results observed, the mathematical model was shown to be suitable when compared to the experimental results, confirming the validation of the mathematical model.
\end{abstract}

Key words: Cadmium, microalgae, heavy metals, mathematical model

\section{INTRODUCTION}

Some heavy metals cause strong impact on the stability of ecosystems and cause adverse effects in human beings even in amounts of the order of milligrams or micrograms. These metals must be removed from the environment in order to avoid habitat degradation and pollution (Steinkellner et at, 1998). Cadmium accumulates in human tissue in function of its affinity by functional bonding agents such as sulfydryl, hydroxyl, carboxylic and phosphoryl groups. Besides, it competes with the essential elements and may cause inhibition of important enzymatic functions (Baes, 1976; Castro, 2000). Many studies have been based on the effects of the cadmium on: enzymatic activities, phosphorization oxidative, permeability and integrity of the cellular membrane and synthesis of proteins. (Hughes and Poole, 1989; Trevors et al., 1986).

The main cadmium applications are found in the batteries production (Ni-Cd), in the manufacturing of pigments for ceramic materials, in the PVC (polyvinyl chloride) stabilization agents and in galvanoplastics processes. It is vital to limit the concentration of these metals in the sources of human consumption. According to our legislation, the content of these elements in waters aimed at the domestic supply should not exceed $20 \mu \mathrm{gL}^{-1}$ and in the case of the cadmium; the upper limit is of $1 \mu \mathrm{gL}^{-1}$. (Castro, 2000).

Generally, the treatment of metal-contaminated effluents includes physical-chemical processes such as flocculation and/or precipitation, electrolysis, crystallization and adsorption. However, these processes are expensive and produce new residuals, thus changing the type of problem. The search for cheaper and definitive solutions led to the development of technologies based on the use of microorganisms as heavy metals removing agents (Ting et al, 1989).

Microorganisms have been commonly reported to be capable of sequestering heavy metals and concentrating them up to several thousand times

\footnotetext{
* Author for correspondence
} 
(or more) over them. The sequestering capacity as well as accumulation mechanisms can vary thoroughly in agreement with the microbial species. External factors as $\mathrm{pH}$, temperature, absence or presence of nutrients and other metals also influence in the mechanism actuate and, consequently, in the efficiency and accumulation selectivity (Crist et al., 1988; Nakagima and Sakaguchi, 1986).

In this work, the uptake of cadmium by the microalgae Pseudokirchneriella supcapitata was evaluated.

\section{MATERIALS AND METHODS}

\section{Organism}

The microorganism used in the present work was the unicellular microalgae Pseudokirchneriella supcapitata, obtained from samples collected in the Ecotoxicology Laboratory - Universidade Federal da Bahia (UFBA).

\section{Growth Medium}

The growth medium was prepared with deionized water and sterilized in autoclave at pressure of 1.5 $\mathrm{kgf} / \mathrm{cm}^{2}$ and temperature of $127^{\circ} \mathrm{C}$. Soon after, 100 $\mathrm{mL}$ of $P$. supcapitata was added in $1 \mathrm{~L}$. Table 1 presents the culture medium composition.

\section{Experimental Cultures}

The second group of experiments was conducted using the same culture conditions mentioned above. After $60 \mathrm{~h}$ of inoculation, the cadmium was added at an initial concentration of $2 \times 10^{-5} \mathrm{molL}^{-1}$. Soon after, samples were collected at several time intervals.The third group of experiments was performed in order to evaluate the cadmium effect on the algae growth. The cadmium was added along with the inoculum in order to observe the algae behavior. Initial concentration of $\mathrm{Cd}$ was $2 \times 10^{-5} \mathrm{molL}^{-1}$.

Table 1 - Composition of growth medium

\begin{tabular}{l|c}
\hline \multicolumn{1}{c|}{ Components } & Concentration $\left.\mathbf{( m o l L}^{-1}\right)$ \\
\hline Calcium Nitrate Tetrahydrate & 0.17 \\
Potassium Nitrate & 0.99 \\
Magnesium Sulphate & 0.12 \\
Potassium Phosphate & 0.23 \\
Copper Sulphate Pentahydrate & $0.12 \times 10^{-3}$ \\
Ammonium Molybdate Tetrahydrate & $0.05 \times 10^{-3}$ \\
Zinc Sulphate & $0.02 \times 10^{-3}$ \\
Manganese Nitrate & $0.24 \times 10^{-3}$ \\
Monohydrate Citric Acid & $0.46 \times 10^{-3}$ \\
Boric Acid & $0.97 \times 10^{-3}$ \\
Ferric Chloride & $6.04 \times 10^{-3}$ \\
Ferrous Sulphate Heptahydrate & $2.24 \times 10^{-3}$ \\
Hydrated Ferric Citrate & $4.85 \times 10^{-3}$ \\
Sodium Bicarbonate & $0.18 \times 10^{-3}$ \\
\hline
\end{tabular}

Font:[PT0001EC-UFBa]

\section{Analysis of the Metal}

The analysis of the residual metal concentrations in the solution and in the membrane was done by Atomic Absorption Spectroscopy (Varian).

\section{Mathematical Modeling}

The phenomenon of metal uptake by the microorganisms is quite complex: the actual attachment of the metal ions on the cellular surface may include the physical adsorption, ion exchange and chemisorption. In this work, the term adsorption is used to describe any of these possible modes of interactions between the metal ion and the surface of the cells without distinction. The uptake of metal ions by microorganisms occurs in two stages:

$1^{\text {st }}$ ) Rapid uptake (passive uptake)

$2^{\text {nd }}$ ) Slower uptake (active uptake)

During the passive uptake, the metal ions are adsorb onto surface of the cells within a few 
seconds or minutes. In the second uptake stage, the metal ions are transported across the cell membrane and into the cytoplasm. The following suppositions are made in the modeling of the uptake process:

(i) The metal in solution at the cell surface, $\mathrm{m}$ (mmol metal/L), is in equilibrium with the metal adsorbed on the cell, $\mathrm{C}_{1}$ (mmol metal/mg cell dry wt). A linear relationship between these two is assumed:

$$
\mathrm{m}=\mathrm{KC}_{1}
$$

where $\mathrm{K}=$ adsorption constant $(\mathrm{mg}$ cell dry wt/L)

(ii) The metal ion adsorbed on the cell surface traverses the cell membrane through the agency of carrier molecules present on both sides of the membrane. The carrier mediated mechanism is analogous to an enzyme-substrate coupling scheme:

$$
\mathrm{C}_{1}+\mathrm{E} \underset{\mathrm{k}_{-1}}{\stackrel{\mathrm{k}_{1}}{\rightleftharpoons}} \mathrm{CE} \underset{\mathrm{k}_{-2}}{\stackrel{\mathrm{k}_{2}}{\rightleftharpoons}} \mathrm{C}_{2}+\mathrm{E}
$$

where: $C_{1}=$ extracellular metal concentration $(\mathrm{mmol} / \mathrm{L})$

$\mathrm{C}_{2}=$ intracellular metal concentration $(\mathrm{mmol} / \mathrm{L})$

$\mathrm{E}=$ carrier concentration $(\mathrm{mmol} / \mathrm{L})$

$\mathrm{CE}=$ metal-carrier complex concentration $(\mathrm{mmol} / \mathrm{L})$

$\mathrm{k}_{1}, \mathrm{k}_{-2}=$ chemical reaction rate constants (mg/mmol.h)

$\mathrm{k}_{-1}, \mathrm{k}_{2}=$ chemical reaction rate constants $\left(\mathrm{h}^{-1}\right)$

(iii) The diffusion of the metal-carrier complex CE through the cell membrane is very rapid and the concentrations of $\mathrm{E}$ and $\mathrm{CE}$ are small compared with $\mathrm{C}_{1}$ and $\mathrm{C}_{2}$, the metal ion concentrations outside and inside the cells, respectively.

iv) Pseudo-steady state is assumed; the is no net accumulation of the metal-carrier complex and $\mathrm{d}(\mathrm{CE}) / \mathrm{dt}=0$.

(v) On a unit volume basis, the carrier content of each cell is essentially constant, and so the total carrier concentration in the system, $\mathrm{E}_{\mathrm{t}}$, is given by

$$
\mathrm{E}_{\mathrm{t}}=[\mathrm{E}]+[\mathrm{CE}]
$$

(vi) One mole of carrier reacts with 1 mol metal ion to produce $1 \mathrm{~mol}$ metal-carrier complex.

From assumption (iv), the reaction velocity $\mathrm{v}$ for the formation and decomposition of the metalcarrier complex is given by:

$$
\begin{aligned}
& \frac{\mathrm{d}[\mathrm{CE}]}{\mathrm{dt}}=\mathrm{k}_{1}\left[\mathrm{C}_{1}\right][\mathrm{E}]-\mathrm{k}_{-1}[\mathrm{CE}]=0 \\
& \mathrm{v}=\frac{\mathrm{d}\left[\mathrm{C}_{2}\right]}{\mathrm{dt}}=\mathrm{k}_{2}[\mathrm{CE}]-\mathrm{k}_{-2}\left[\mathrm{C}_{2}\right][\mathrm{E}]
\end{aligned}
$$

Using equations (3) - (5), we obtain:

$$
\mathrm{v}=\mathrm{E}_{\mathrm{t}} \frac{\mathrm{Z}_{1}\left[\mathrm{C}_{1}\right]-\mathrm{Z}_{2}\left[\mathrm{C}_{2}\right]}{1+\mathrm{Z}_{3}\left[\mathrm{C}_{1}\right]+\mathrm{Z}_{4}\left[\mathrm{C}_{2}\right]}
$$

and

$$
\mathrm{CE}=\mathrm{E}_{\mathrm{t}} \frac{\mathrm{Z}_{3}\left[\mathrm{C}_{1}\right]-\mathrm{Z}_{4}\left[\mathrm{C}_{2}\right]}{1+\mathrm{Z}_{3}\left[\mathrm{C}_{1}\right]+\mathrm{Z}_{4}\left[\mathrm{C}_{2}\right]}
$$

where:

$$
\begin{aligned}
& \mathrm{Z}_{1}=\frac{\mathrm{k}_{1} \mathrm{k}_{2}}{\mathrm{k}_{-1}+\mathrm{k}_{2}} \\
& \mathrm{Z}_{2}=\frac{\mathrm{k}_{-1} \mathrm{k}_{-2}}{\mathrm{k}_{-1}+\mathrm{k}_{2}} \\
& \mathrm{Z}_{3}=\frac{\mathrm{k}_{1}}{\mathrm{k}_{-1}+\mathrm{k}_{2}} \\
& \mathrm{Z}_{4}=\frac{\mathrm{k}_{-2}}{\mathrm{k}_{-1}+\mathrm{k}_{2}}
\end{aligned}
$$

From assumption (iii), [CE] is small, so from equation (6), $1+Z_{3}\left[C_{1}\right]+Z_{4}\left[C_{2}\right] \approx 1$. Hence equation (6) approximates to

$$
\mathrm{v}=\mathrm{E}_{1}\left\{\mathrm{Z}_{1}\left[\mathrm{C}_{1}\right]-\mathrm{Z}_{2}\left[\mathrm{C}_{2}\right]\right\}
$$

Replacing $\mathrm{E}_{\mathrm{t}}$ by the product $\mathrm{xp}$, where $\mathrm{x}$ is cell dry weight $(\mathrm{mg} / \mathrm{L})$ and $\mathrm{p}$ is the carrier content of the cells $(\mathrm{mmol} / \mathrm{mg})$,

$$
\mathrm{v}=\operatorname{xp}\left\{\mathrm{Z}_{1}\left[\mathrm{C}_{1}\right]-\mathrm{Z}_{2}\left[\mathrm{C}_{2}\right]\right\}
$$


By defining $R_{1}$, the carrier rate constant, as $p\left(Z_{1}\right)$ and $R_{2}$, the ratio of rate constants, as $Z_{2} / Z_{1}$ and writing $\mathrm{v}$ as $\mathrm{d}\left(\mathrm{x}\left[\mathrm{C}_{2}\right]\right) / \mathrm{dt}$, one obtains

$$
\frac{\mathrm{d}\left(\mathrm{x}\left[\mathrm{C}_{2}\right]\right)}{\mathrm{dt}}=\mathrm{xR}_{1}\left\{\left[\mathrm{C}_{1}\right]-\mathrm{R}_{2}\left[\mathrm{C}_{2}\right]\right\}
$$

The metal mass balance gives

$$
\mathrm{A}=\mathrm{m}+\mathrm{x}\left\{\left[\mathrm{C}_{1}\right]+\left[\mathrm{C}_{2}\right]\right\}
$$

where $\mathrm{A}$ is the total metal concentrations in a unit volume of system and $m$ is the concentration of the metal ion in solution.

Substituting (1) and (11) into equation (10), one obtains:

$$
\frac{\mathrm{d}\left(\mathrm{x}\left[\mathrm{C}_{2}\right]\right)}{\mathrm{dt}}=\frac{\mathrm{xR}}{\mathrm{K}+\mathrm{x}} \cdot\left\{\mathrm{A}-\left[\mathrm{C}_{2}\right]\left(\mathrm{x}+\mathrm{R}_{2}(\mathrm{~K}+\mathrm{x})\right)\right\}
$$

This final expression provides a description of the model from which an analytical solution may be obtained.

The cells growth (x) for the equation (12), can followed three models

I.. Uptake by viable cells without growth, $\mathrm{x}=\mathrm{x}_{\mathrm{o}}$

II. Uptake by cells with linear growth

$$
\frac{\mathrm{dx}}{\mathrm{dt}}=\mathrm{L}
$$

where $\mathrm{L}$ is the linear growth rate (mg dry wt/Lh).

III. Uptake by cells with exponential growth,

$$
\frac{\mathrm{dx}}{\mathrm{dt}}=\mu \mathrm{x}
$$

where $\mu$ is the exponential growth rate $\left(\mathrm{h}^{-1}\right)$.

\section{Estimation of model parameters $K_{\mathbf{1}} R_{\mathbf{1}}$ and $R_{\mathbf{2}}$}

At the initial stage of the metal uptake, only surface adsorption is significant so that $\left[\mathrm{C}_{2}\right]$ my be assumed to be zero in equation (11). At time $t=0$, $\mathrm{x}=\mathrm{x}_{0}$. Hence, with equation (1), one obtains

$$
\mathrm{K}=\frac{\mathrm{m}}{\mathrm{A}-\mathrm{m}} \mathrm{x}_{0}
$$

An estimate of the adsorption constant $\mathrm{K}$ can therefore be made using results obtained at the beginning of the experiments.

From equations (1) and (11), the intracellular metal concentration $\mathrm{x}\left[\mathrm{C}_{2}\right]$ my be writen as

$$
\mathrm{x}\left[\mathrm{C}_{2}\right]=\frac{\mathrm{KA}-\mathrm{m}(\mathrm{K}+\mathrm{x})}{\mathrm{K}}
$$

Substituing equations (1) and (16) into equation (10), yelds

$$
\begin{aligned}
& \frac{\mathrm{d}\{(\mathrm{KA}-\mathrm{m}(\mathrm{K}+\mathrm{x})) / \mathrm{K}\}}{\mathrm{dt}}= \\
& \frac{\mathrm{xmR} \mathrm{R}_{1}}{\mathrm{~K}}-\frac{\mathrm{KA}-\mathrm{m}(\mathrm{K}+\mathrm{x})}{\mathrm{K}} \mathrm{R}_{1} \mathrm{R}_{2}
\end{aligned}
$$

By defining two variables $\alpha$ and $\beta$ as

$$
\alpha=\frac{\mathrm{KA}-\mathrm{m}(\mathrm{K}+\mathrm{x})}{\mathrm{K}} \quad \beta=\frac{\mathrm{xm}}{\mathrm{K}}
$$

equation (17) becomes

$$
\frac{\mathrm{d} \alpha}{\mathrm{dt}}=\beta \mathrm{R}_{1}-\alpha \mathrm{R}_{1} \mathrm{R}_{2}
$$

From experimental data, $\alpha$ was able to be expressed as a second degree polynomial function of $\mathrm{t}$, and so $\mathrm{d} \alpha / \mathrm{dt}$ expressed as a function of $\mathrm{t}$. Likewise, $\beta$ was able to be calculated using values of $\mathrm{x}$ and $\mathrm{m}$ at different times. By substituting $\mathrm{d} \alpha / \mathrm{dt}, \alpha$ and $\beta$ evaluated at different times into equation (18), the carrier rate constant $R_{1}$ and the ratio of rate constants $R_{2}$ were estimated using a linear least-square analyses routine (MATLAB).

Having obtained an estimate of the three constants $\left(\mathrm{K}, \mathrm{R}_{1}\right.$ e $\mathrm{R}_{2}$ ) from experimental data, equation (12) along with the growth model that in this case presented a exponential behavior, equation (14) was able to be solved by numerical means using Runge Kutta method.

\section{RESULTS AND DISCUSSION}

The results of the experiments showed that the metal ion concentration was not lost during culture, sampling and analysis. This showed that decrease in the metal residual concentration on 
algae-metal experiments could be attributed to the removal by the algae cells.

\section{Cell growth for the first and second groups of experiments}

At $25^{\circ} \mathrm{C}$ and under constant light, the culture grew normally. Growth experimental data were tested using linear and exponential models. The most suitable model for $P$. subcapitata was the exponential growth model.

The exponential model follows the equation (14), $\frac{\mathrm{dx}}{\mathrm{dt}}=\mu \mathrm{x}$, which analytical integration of the equation whit the initial conditions is presented as follows

$$
x=x_{0} e^{\mu \cdot t}
$$

where, $\mu$ is the specific growth rate considered as constant during experiments. The model parameters were found from experimental data using the approximation of the least-square, thus obtaining the following equation:

$$
x=16,959 e^{0,00685 \cdot t}
$$

The slope comparing the model, equation (20) to the experimental values is presented in Fig. 2, first group; one observes that the exponential model represents satisfactorily the $P$. subcapitata growth behavior.

The second experiment was conducted with the objective of evaluating the removal of cadmium after $60 \mathrm{~h}$ incubation and also to observe the cellular growth with the addition of cadmium to the culture medium. After $60 \mathrm{~h}$ of algae development, cadmium as cadmium nitrate was added to the culture medium (final concentration $\left.2 \times 10^{-2} \mathrm{mmolL}^{-1}\right)$. The cellular growth suffered no alterations in the second group of experiments.

\section{Estimative of parameters $K, R_{1}$ e $R_{2}$ for the second group of experiments}

The uptake of cadmium from the culture medium is analyzed for the calculation of the constants $\mathrm{K}$,

$\mathrm{R}_{1}$ and $\mathrm{R}_{2}$. The estimative of the adsorption constant $\mathrm{K}$ followed the procedure of the anterior section,

using the equation (15), $K=\frac{m}{A-m} x_{0}$.
Where $\mathrm{m}=0.01891 \mathrm{mmolL}^{-1}$ (metal concentration in the solution at the first moments, in other words, $\mathrm{t}=0.25 \mathrm{~h}), \mathrm{A}=2 \times 10^{-2} \mathrm{mmolL}^{-1}$ and $\mathrm{x}_{0}=16.15$ $\mathrm{mgL}^{-1}$ (cellular concentration at the first moments, $\mathrm{t}=0.25 \mathrm{~h}$ ). Therefore, the value of the adsorption constant is $\mathrm{K}=280.18 \mathrm{mgL}^{-1}$. The estimative of $\mathrm{R}_{1}$ and $R_{2}$ was given as follows: Experimental data from 0.25 to 72 hours were initially used, period in which the adsorption into the inner of the cell was intense; after this period, although adsorption at the cell wall still occurs, the adsorption into the inner of the cell is almost null.

Using equation (18), $\frac{\mathrm{d} \alpha}{\mathrm{dt}}=\beta \mathrm{R}_{1}-\alpha \mathrm{R}_{1} \mathrm{R}_{2}$, where

by definition

$$
\alpha=\frac{\mathrm{KA}-\mathrm{m}(\mathrm{K}+\mathrm{x})}{\mathrm{K}} \text { and } \beta=\frac{\mathrm{xm}}{\mathrm{K}}
$$

The values of $\alpha$ and $\beta$ were calculated from the adsorption constant $\mathrm{K}$, the total cadmium concentration $\mathrm{A}$ and from the values of $\mathrm{m}$ and $\mathrm{x}$ that vary with time during the experiments. The variable $\alpha$ was adjusted to a second degree polynomial in function of time.

An equations system similar to equation (18) was constructed. The system was solved using the MATLAB software with optimization through the use of the least-square method. Fig. 1 shows the uptake of cadmium with initial concentration of $2 \times 10^{-2} \mathrm{mmolL}^{-1}$, under standard conditions. The metal ion concentration dropped $5.5 \%$ at the 15 initial minutes. A slow uptake of cadmium was observed later. The model proposed in this work is in agreement with the instant decrease observed in the metal residual concentration in the solution caused by the metal ion adsorption at the algae cell walls. A slow increase in the metal adsorption was also observed. As observed from the Figure, the experimental results approximated to the simulated model.

Cadmium specific adsorption (mmol $\mathrm{Cd} / \mathrm{mg}$ dry cell) is also presented in Fig. 1. The model became again consistent, once an increase on the metal ions in the cell was observed. The increase on the metal ion intracellular concentration was due to the metal ions membrane transportation; this effect decreased with time due to the cell continuous growth and the reduction in the metal ions concentration in the solution. 


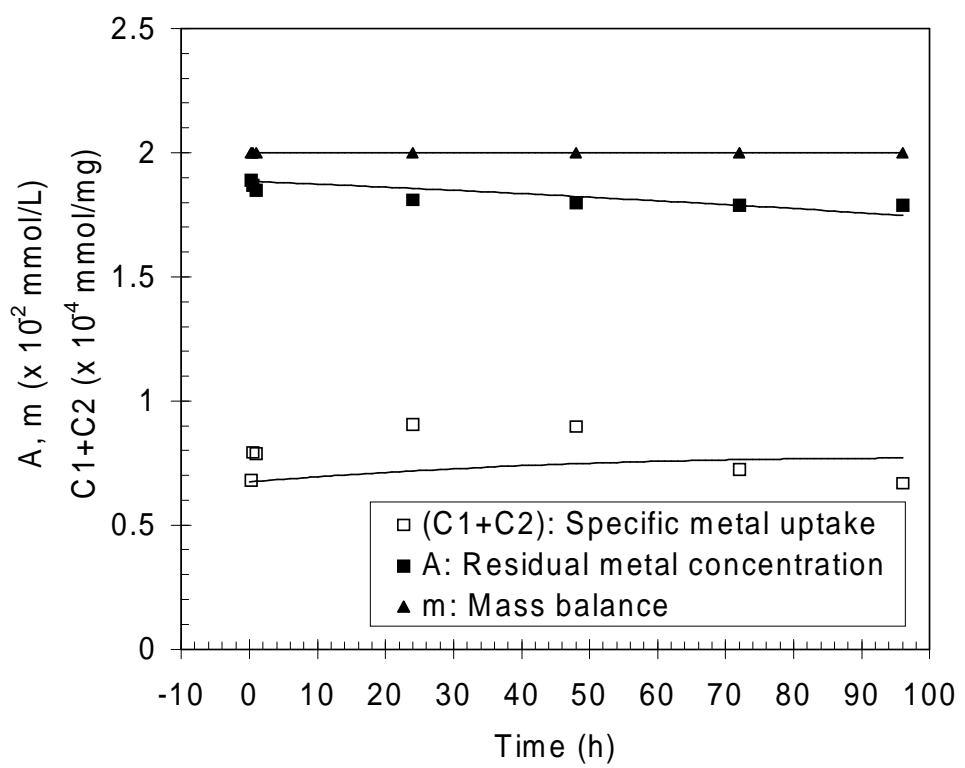

Figure 1 - Uptake of cadmium at $25^{\circ} \mathrm{C}$ with illumination. The model results are shown as solid lines.

\section{Cellular growth for the third group of experiments \\ The exponential model presented a better} correlation if compared to the linear model, also presenting a growth behavior similar to the first and second groups of tests. The exponential growth equation, according to procedure previously described, is presented below:

$$
x=12,372 e^{0,00732 \cdot t}
$$

Fig. 2 shows the graph comparing the exponential model to experimental data. Addition of cadmium at the beginning of the experiment inhibited the algae growth that developed with a slower velocity.

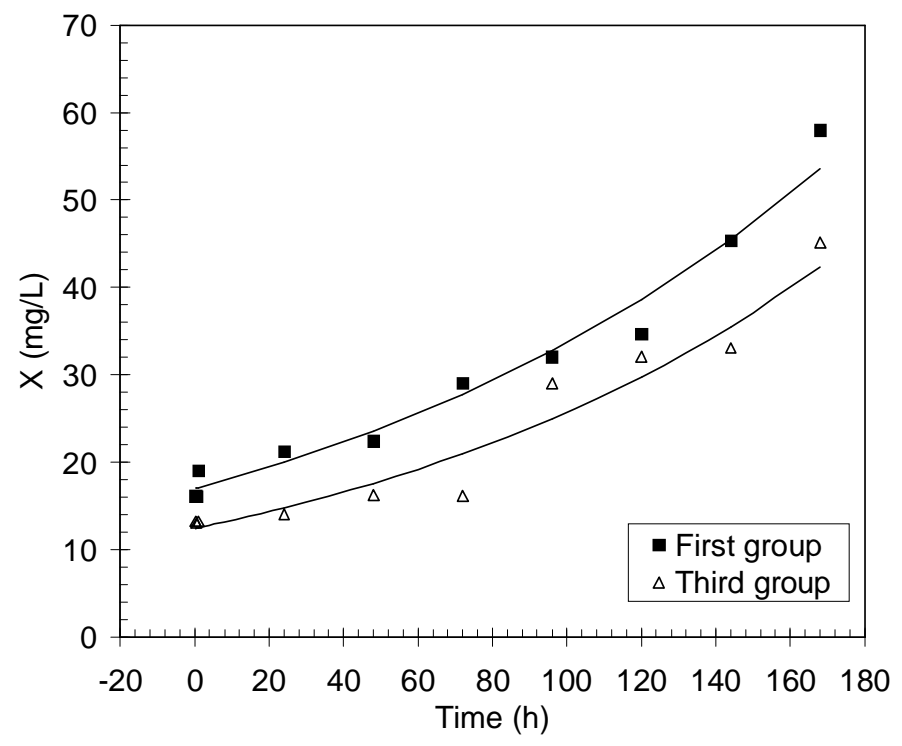

Figure 2 - Algae growth slopes without addition of cadmium (first group) and with addition of cadmium since the beginning of the inoculation (third group). 
Fig. 3 shows the graph of the cadmium adsorption when it was added at the beginning of the cellular growth. A higher absorption of cadmium ions occurred at the beginning of the experiment followed by a slow absorption.

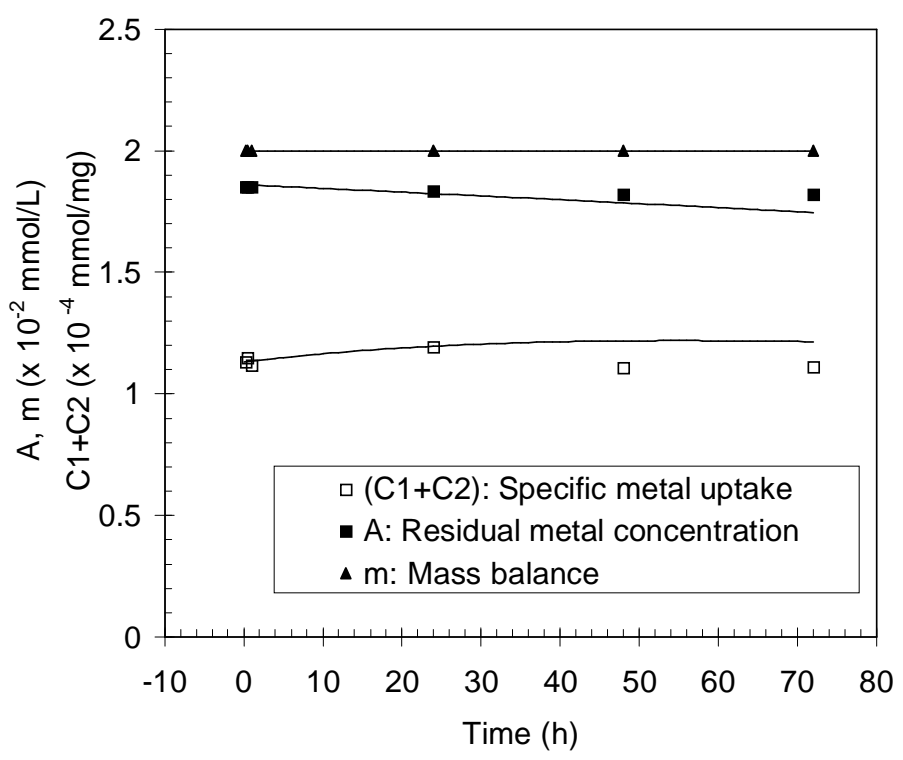

Figure 3 - Uptake of cadmium at $25^{\circ} \mathrm{C}$ with illumination. The model results are shown as solid lines.

Table 2 shows the values of the constants related to both the groups.

Table 2 - Model parameters

\begin{tabular}{c|cc|c|c|c}
\hline Experiments & \multicolumn{2}{c|}{$\begin{array}{c}\text { Medium contitions } \\
{ }^{\mathbf{o}} \mathbf{C} \mathbf{~} \mathbf{H}\end{array}$} & $\begin{array}{c}\mathbf{K} \\
(\mathbf{m g} / \mathbf{L})\end{array}$ & $\begin{array}{c}\mathbf{R}_{\mathbf{1}} \\
\left(\mathbf{h}^{-1}\right)\end{array}$ & $\begin{array}{c}\mathbf{R}_{\mathbf{2}} \\
(\mathbf{a d . l})\end{array}$ \\
\hline $2^{\text {nd }}$ group & 25 & 7.0 & 280.18 & 0.004 & 1.33177 \\
$3^{\text {rd }}$ group & 25 & 7.0 & 164.6 & 0.0045 & 4.4258 \\
\hline
\end{tabular}

\section{CONCLUSIONS}

The mathematical model developed describes the uptake of cadmium metal ions by $P$. subcapitata. The model is described by two removal mechanisms: surface adsorption and transportation through the membrane. It was observed that a growth inhibition occurred when cadmium was added along with the inoculum in the $3^{\text {rd }}$ group. The surface adsorption (passive adsorption) involved no metabolic process and did not either requires any energy from the cells. The transportation through the membrane (activate transportation) depends on the metabolic process, light intensity (in order to perform photosynthesis), and temperature. In this work, the temperature was maintained as constant at approximately $25^{\circ} \mathrm{C}$ and $\mathrm{pH}=7.0$.

The effect of a variation under medium conditions reflected on the changes of the model parameters $\mathrm{K}, \mathrm{R}_{1}$ and $\mathrm{R}_{2}$. It was observed that changes on the model parameters occurred with the addition of cadmium with the growth and addition after 6hours growth.

The adsorption constant $\mathrm{K}$ is a property characteristic of the cell surface and it is expected to be dependent on the different medium conditions, particularly composition and $\mathrm{pH}$. The constant of the rate $R_{1}$ and the constant of the transporter $R_{2}$ are medium-dependent. The model validity was confirmed for the system, once $P$. 
subcapitata accumulated cadmium ions from the solution.

\section{ACKNOWLEDGMENTS}

We are grateful to CAPES for financial support.

\section{RESUMO}

Neste trabalho utilizou-se a microalga Pseudokirchneriella supcapitata para a remoção do cádmio em líquidos. A metodologia consistiu de três conjuntos de experimentos: o primeiro conjunto teve como objetivo a avaliação do crescimento da alga, o segundo foi à avaliação da remoção de cádmio e o terceiro a avaliação do crescimento da alga sendo adicionado o cádmio junto com o inóculo no tempo igual a zero, também foi avaliada a remoção de cádmio neste terceiro experimento. $\mathrm{O}$ acúmulo de íons metálicos pela alga ocorre em duas etapas: uma absorção muito rápida (adsorção passiva) seguida por uma absorção mais lenta (absorção ativa) Desenvolveuse um modelo matemático baseado na absorção da superfície e no transporte para o interior da membrana celular. A obtenção dos parâmetros cinéticos do modelo de simulação foi obtida experimentalmente. Pelos resultados observados o modelo matemático proposto mostrou-se adequado quando comparado aos resultados experimentais, confirmando a validação do modelo matemático proposto.

\section{REFERENCES}

Assis, J. C. (1998), Água sob medida. Agroanalysis, 18, 83-88.

Baes, C. F. et al. (1979), The Hidrollysis of Cations, New York: John W. and Sons. pp. 4, 6, 15 e 24.

Castro, M. T. P. (2000), Tese de Doutorado Unicamp. pp.33-39.

Crist, R. H. et al. (1988), Interactions of metals and prótons with algae, Env. Sc. Technology., USA, 22, 755-760.

Gadd, G. M. (1988), Acumulation of metals by microorganisms and algae, Biotechonology $-A$ comprehensive treatise, Winheim, $\mathbf{6 b}, 401-433$.

Hughes, M. N. and Poole, R. K. (1989), Metals and Microorganisms. Londres: Chapman and Hall Ltd.
Nakajima, A. and Sakagushi, T. (1986), Selective accumulation of heavy metals by microorganisms, Appl. Biotechonol., Berlim, 24, 59-64.

Steinkellner H. et al. (1998), Genotoxic effects of heavy metals: comparative investigation with plant bioassays. Environ Mol Mutagen, 31-91.

Ting, Y. P. et al. (1989). Uptake of cadmium and zinc by algae Chlorella vulgaris, Biotechnol., Bioeng. , New York, 34, 990-999.

Trevors, J. T. et al. (1986), Cadmium transport resistente and toxicity in bacteria, algae and fungi. Microbiol., Otawa, 32, 447-467.

Casiraghi, M. P. (2003), Remoção de Cádmio em Líquidos pela Microalga Pseudokirchneriella supcapitata, Dissertação (Mestrado), Universidade Federal da Bahia, Brazil.
Received: June 18, 2004; Revised: October 19, 2004; Accepted: May 23, 2005. 